\title{
SOLUTION OF THE SYSTEM OF PARAMETRIC EQUATIONS OF THE SESSILE DROP
}

\author{
R. ČIUPAILA ${ }^{1}$ and M. SAPAGOVAS ${ }^{1,2}$ \\ ${ }^{1}$ Vilnius Gediminas Technical University \\ Saulètekio 11, 2054 Vilnius, Lithuania \\ ${ }^{2}$ Institute of Mathematics and Informatics \\ Akademijos 4, Vilnius 2600, Lithuania \\ E-mail: reciup@lrs.lt, m.sapagovas@ktl.mii.lt
}

Received September 17, 2001; revised March 1, 2002

\begin{abstract}
Several models of parameterization for the problem of free surface of the sessile liquid drop with nonlocal integral condition of prescribed volume are considered. The paper aims to obtain for every model specific algebraic connection among physical and geometrical parameters of the problem and compare them. This connection allows to construct the iterative process for the unknown radius of the drop with more simple boundary conditions.

The positiveness of Lagrange multiplier in the problem of constrained minimization as well as uniqueness of positive meaning of the radius of the drop are proven in the paper.
\end{abstract}

Key words: nonlocal boundary conditions, free surface problems, liquid drop.

\section{INTRODUCTION}

The mathematical model of the sessile drop on the horizontal plane is considered. The general, the boundary curve of the sessile or pendant drop cannot be represented by an explicit function, hence the parametric presentation of the solution should be chosen. If the drop is not fixed on the plane by mean of special treatment, the radius of the drop is unknown.

The aim of the paper is to investigate few types of parameterization of the problem, obtaining an algebraic expression for the unknown radius of the drop. It is shown in the paper, that the positive meaning for radius $a$ is unique. The connection received allows us to reduce the problem with nonlocal integral condition to the equivalent problem with an algebraic condition for radius $a$.

Theoretical investigations for the problems of the free surface of the drop widely were considered in the monograph [2]. Some numerical aspects of the problem considered were investigated in the papers $[4 ; 5 ; 6 ; 7]$. Many of the 
problems for the drop are still under research interest [3].

\section{ALGEBRAIC CONNECTION OF THE PARAMETERS FOR DIFFERENTIAL PROBLEM}

Let us use first the parametric presentation of the boundary curve of the drop: $u(s), r(s), s \in[0,1]$, as it is provided in $[4 ; 5]$.

For the symmetric sessile liquid drop of prescribed volume in the field of gravity the problem of free surface can be presented as a constrained minimization of the functional of total energy:

$$
\begin{aligned}
\inf _{(u, r) \in U} E(u(s), r(s))= & \inf _{(u, r) \in U}\left(E_{s}(u(s),\right. \\
& r(s))+E_{p}(u(s), r(s)) \\
& \left.-\lambda\left(V(u(s), r(s))-V_{0}\right)\right),
\end{aligned}
$$

there

$$
\begin{aligned}
U=\left\{u(s) \geq 0, u_{s}^{\prime}(0)=0, u(1)=0, r(0)=0, r(1)=a,\right. & \left.\frac{u_{s}^{\prime}(1)}{\sqrt{{u_{s}^{\prime}}^{2}(1)+{r_{s}^{\prime}}^{2}(1)}}=\cos \gamma\right\} .
\end{aligned}
$$

$E_{p}(u, r), E_{s}(u, r)$ are the gravitational and free surface energy respectively:

$E_{p}(u, s)=\pi \rho g \int_{0}^{1} r(s) r_{s}^{\prime}(s) u^{2}(s) d s, E_{s}(u, s)=2 \pi \sigma \int_{0}^{1} r(s) \sqrt{{u_{s}^{\prime}}^{2}(s)+{r_{s}^{\prime}}^{2}(s)} d s$

where $u(s)$ is a height the crest of the drop, $r(s)$ - radius of the horizontal section, $\sigma$ - surface tension coefficient, $g$ - constant of gravity, $\rho$ - density of the liquid material of the drop, $\lambda$ - Lagrange multiplier, $V_{0}$ - quantity of the liquid in the drop, $\gamma$ - contact (adhesion) angle, $a$ - radius of the base of the drop on the plane, $K=\rho g / \sigma$. The total volume of the liquid in the drop is given as nonlocal condition:

$$
2 \pi \int_{0}^{1} r(s) u(s) r_{s}^{\prime}(s) d s=V_{0}
$$

The variation of the total energy functional provides the differential boundary value problem for parametric equations

$$
\begin{aligned}
& -\frac{d}{d s}\left(\frac{r u_{s}^{\prime}}{\sqrt{\left(u_{s}^{\prime}\right)^{2}+\left(r_{s}^{\prime}\right)^{2}}}\right)+K u r r_{s}^{\prime}-\lambda r r_{s}^{\prime}=0 \\
& -\frac{d}{d s}\left(\frac{r r_{s}^{\prime}}{\sqrt{\left(u_{s}^{\prime}\right)^{2}+\left(r_{s}^{\prime}\right)^{2}}}\right)-K u r u_{s}^{\prime}+\lambda r u_{s}^{\prime}=-\sqrt{\left(u_{s}^{\prime}\right)^{2}+\left(r_{s}^{\prime}\right)^{2}}
\end{aligned}
$$


with additional nonlocal condition (2.4) and boundary conditions (2.2).

Totally for this boundary value problem of two differential parametric equations of the second order six additional conditions are determined: four boundary conditions, nonlocal condition of the total volume of the drop and the condition for unknown radius $r(1)=a$, which could change depending on the physical parameters of the model and treatment of the surface of the plane.

Obtaining an algebraic connection among physical and geometrical parameters of the problem allows us to reduce the problem to equivalent one replacing additional nonlocal integral condition by an algebraic one.

By integrating equation (2.5), as it was proposed in [6] and taking into account conditions (2.2), (2.4), we obtain

$$
-\left.\frac{r(s) u_{s}^{\prime}}{\sqrt{\left(u_{s}^{\prime}\right)^{2}+\left(r_{s}^{\prime}\right)^{2}}}\right|_{0} ^{1}+K \int_{0}^{1} u(s) r(s) r_{s}^{\prime} d s-\lambda \int_{0}^{1} r(s) r_{s}^{\prime}(s) d s=0,
$$

providing

$$
-\frac{r(1) u_{s}^{\prime}(1)}{\sqrt{{u_{s}^{\prime}}^{2}(1)+{r_{s}^{\prime}}^{2}(1)}}+\frac{r(0) u_{s}^{\prime}(0)}{\sqrt{{u_{s}^{\prime}}^{2}(0)+{r_{s}^{\prime}}^{2}(0)}}+\frac{K}{2 \pi} V_{0}-\lambda \int_{0}^{1} r(s) d r(s)=0 .
$$

By using boundary conditions, we get

$$
\frac{\lambda}{2} a^{2}+\cos \gamma a-\frac{K}{2 \pi} V_{0}=0
$$

It follows from (2.7) that

$$
a=-\frac{1}{\lambda} \cos \gamma \pm \sqrt{\frac{1}{\lambda^{2}} \cos ^{2} \gamma+\frac{K}{\lambda \pi} V_{0}} .
$$

If we consider a overhanging drop $(\cos \gamma>0)$, the condition (2.8) provides only one positive solution for $a$ for any nonzero values of physical parameters and the positive $\lambda$. The positiveness of $\lambda$ will be shown later in this paper.

The condition (2.8) is the same, which satisfies the nonparametrical problem of sessile drop. This model could be presented by more simple boundary value problem for a nonlinear differential equation $[2 ; 6]$ :

$$
\left\{\begin{array}{l}
\frac{1}{r} \frac{d}{d r}\left(\frac{r u_{r}^{\prime}}{\sqrt{1+\left(u_{r}^{\prime}\right)^{2}}}\right)-K+\lambda=0, \\
u^{\prime}(0)=0, u(a)=0, \frac{u^{\prime}(a)}{\sqrt{1+u^{\prime 2}(a)}}=\cos \gamma \\
2 \pi \int_{0}^{a} r u d r=V_{0} .
\end{array}\right.
$$

The limits of use of model (2.9) and the necessity to switch to the model (2.5), $(2.6),(2.4),(2.2)$ were provided in [4] for the problem with fixed radius $a$. 


\section{UNIQUENESS OF POSITIVE SOLUTION OF THE PROBLEM}

To prove the uniqueness of the positive solution of the problem we consider type of parametrization of the drop model, which was proposed by in $[1 ; 2]$ in the shape of boundary value problem for three differential equations of the first order:

$$
\begin{aligned}
& \frac{d u}{d s}=\sin \varphi, \\
& \frac{d r}{d s}=\cos \varphi, \\
& \frac{d \varphi}{d s}=K u-\frac{1}{r} \sin \varphi-\lambda,
\end{aligned}
$$

with the boundary conditions

$$
u(1)=0, r(0)=0, r(1)=a, \varphi(0)=0,
$$

and nonlocal condition of the volume of the drop:

$$
2 \pi \int_{0}^{1} r u \cos \varphi d s=V_{0}
$$

where $\varphi=\varphi(s)$ is an angle between the tangent of the curve and the abscissa axis, $\varphi \in[0,-\pi)$.

We show that connection (2.8) is the same for the problem (3.1) - (3.5). By expressing of the unknown $u$ from the equation (3.3)

$$
u=\frac{1}{K} \frac{d \varphi}{d s}+\frac{1}{r} \frac{1}{K} \sin \varphi+\frac{\lambda}{K},
$$

and putting it to the nonlocal condition (3.5), we obtain:

$$
\begin{aligned}
& \int_{0}^{1} r\left(\frac{d \varphi}{d s}+\frac{1}{r} \sin \varphi+\lambda\right) \cos \varphi d s=\frac{V_{0} K}{2 \pi}, \\
& \int_{0}^{1} r \cos \varphi d \varphi+\int_{0}^{1} \sin \varphi \cos \varphi d s+\int_{0}^{1} \lambda r \cos \varphi d s=\frac{V_{0} K}{2 \pi} .
\end{aligned}
$$

By using the condition (3.2), we get

$$
\int_{0}^{1} r d \sin \varphi+\int_{0}^{1} \sin \varphi d r+\lambda \int_{0}^{1} r d r=\frac{V_{0} K}{2 \pi},
$$


and, after simple computation,

$$
\left.r(s) \sin \varphi\right|_{0} ^{1}-\int_{0}^{1} \sin \varphi d r+\int_{0}^{1} \sin \varphi d r+\left.\lambda \frac{r^{2}(s)}{2}\right|_{0} ^{1}=\frac{V_{0} K}{2 \pi}
$$

providing $a \sin \varphi(1)+\frac{\lambda}{2} a^{2}=\frac{V_{0} K}{2 \pi}$, where

$$
\varphi(1)=\varphi_{1}=\frac{\pi}{2}+\gamma, 0 \leq \gamma<\frac{\pi}{2}
$$

Then $a^{2}+2 \frac{1}{\lambda} \sin \varphi_{1} a-\frac{V_{0} K}{\lambda \pi}=0$ provides

$$
a=-\frac{1}{\lambda} \sin \varphi_{1} \pm \sqrt{\left(\frac{1}{\lambda} \sin \varphi_{1}\right)^{2}+\frac{V_{0} K}{\lambda \pi}}
$$

and, taking into account (3.6),

$$
a=-\frac{1}{\lambda} \cos \gamma \pm \sqrt{\left(\frac{1}{\lambda} \cos \gamma\right)^{2}+\frac{V_{0} K}{2 \pi}}
$$

giving the same condition as (2.8).

The uniqueness of positive radius $a$ we prove by the lemma.

Lemma 3.1. The Lagrange multiplier $\lambda$ is positive for physical and geometrical parameters of the problem (3.1) - (3.5).

Let us consider the equation (3.3). According to the method of parametrization, $\varphi_{s}^{\prime} \leq 0$ along the boundary curve of the drop starting from $\varphi=0$ to $-\pi<\varphi \leq 0$.

As at the point $s=0, \varphi(0)=0$, we get

$$
\left.\frac{d \varphi}{d s}\right|_{s=0}=K u_{0}-\left.\frac{\sin \varphi}{r}\right|_{s=0}-\lambda=K u_{0}-\left.\frac{\cos \varphi \varphi_{s}^{\prime}}{r_{s}^{\prime}}\right|_{s=0}-\lambda
$$

Then, taking into account the equation (3.2), we obtain

$$
\left.\frac{d \varphi}{d s}\right|_{s=0}=\frac{K u_{0}-\lambda}{2} \leq 0
$$

providing

$$
\lambda \geq K u_{0}>0
$$


where $u_{0}$ is the top height of the drop. By acknowledging condition (3.8) we may realize the only one positive value for $a$ as it follows from (3.7).

As algebraic connection (3.7) is the same as (2.8), results of lemma could be used for the problem (2.1), (2.2), (2.4) as well.

The obtained algebraic connection (3.7) and condition for $\lambda$ evaluation (3.8) could be used for further investigation as well as construction of numerical methods for the solution of problems considered as it was done for nonparametrical models in $[6 ; 7]$, where these conditions were used for the proof of the existence and uniqueness of the solution of the problem.

\section{REFERENCES}

[1] R. Finn. Cappilarity phenomenons. Uspekhi math. nauk, 29(4), 131 - 152, 1974. (in Russian)

[2] R. Finn. Equilibred Cappilary surfaces. Mathematical theories. Moscow, 1986. (in Russian)

[3] R. Finn. Cappilary surface interfaces. Notices Amer. Math. Soc., 46(7), 770 - 781, 1999.

[4] R. Čiegis and R. Čiupaila. On the variational-difference method for one problem of conditional minimization. Liet. mat. rink., 30(4), $810-822$, 1990. (in Russian)

[5] R. Čiegis and R. Čiupaila. Some aspects of the solution of static liquid metal contact problems. Liet. mat. rink., 30(2), 392 - 404, 1990. (in Russian)

[6] M. Sapagovas. The finite difference method for the equation of the sessile drop. In: H. Amann et al.(Ed.), Navier-Stokes equations and related nonlinear problems. $\mathrm{VSP} / \mathrm{TEV}, 255-263,1998$.

[7] M. Sapagovas. On the investigation of the convergence of finite difference method for the Neumann boundary problem of the surface of the drop. Differ. equations, 37(7), 2001. (in Russian)

\section{Lašo paviršiaus parametrinių lygčių sistemos sprendimas}

R. Čiupaila, M. Sapagovas

Lašo, gulinčio ant horizontalios plokštumos, laisvo paviršiaus formai nustatyti nagrinėjami keli parametrizavimo modeliai. I uždavinio formuluotę įtraukiama nelokali integralinè sąlyga. Straipsnyje ieškoma algebrinès išraiškos, sujungiančios fizikinius ir geometrinius uždavinio parametrus. Ši algebrinè išraiška yra ta pati tiek dviejų antros eilès lygčiu sistemos modeliui, tiek trijų pirmos eilès lygčiu sistemos modeliui. Taip pat yra ịrodomas Lagranžo daugiklio teigiamumas bei teigiamos lašo pagrindo spindulio reikšmès vienatinumas. 